\title{
PERKEMBANGAN POLITIK HUKUM PERADILAN ADAT
}

\author{
Herlambang P. Wiratraman* \\ Departemen Hukum Tata Negara, Fakultas Hukum Universitas Airlangga \\ Visiting Research Scholar Norwegian Center for Human Rights (NCHR), \\ Faculty of Law University of Oslo \\ Jalan Dharmawangsa Dalam Selatan, Airlangga, Gubeng, Kota Surabaya, Jawa Timur 60286
}

\begin{abstract}
The politics of decentralization after Suharto provided more space in the discourse of adat justice in Indonesia. The problem is that the legal political process does not stand in empty space. Adat justice issues in the political system that regulates political-economic authority, which is supported by the character of the persistence of a network of oligarchs, massive destruction of destructive natural resources, and corrupt and feudalistic bureaucracies. This article encourages local democracy that fosters broad community participation, including encouraging the work of adat justice, has paralyzed the empowerment of the judiciary itself, so that the legal politics of adat justice openly triggers a symbol of certain feudalism protection.
\end{abstract}

Keywords: adat justice, legal system, legal politics.

\section{Intisari}

Konteks politik desentralisasi pasca Suharto memberi ruang lebih dalam diskursus peradilan adat di Indonesia. Masalahnya, proses politik hukum itu tak berdiri di ruang kosong. Peradilan adat berinteraksi dalam sistem politik yang menampilkan kuasa ekonomi-politik, yang dipenuhi dengan karakter bertahannya jaringan oligarki, eksploitasi sumberdaya alam yang masif nan merusak, serta birokrasi yang korup dan feodalistik. Artikel ini memperlihatkan demokratisasi lokal yang menumbuhkan partisipasi masyarakat secara luas, termasuk mendorong bekerjanya mekanisme peradilan adat, telah melumpuhkan keberdayaan peradilan itu sendiri, sehingga politik hukum peradilan adat, secara bertahap melahirkan simbolisasi kuasa feodalisme tertentu.

Kata Kunci: peradilan adat, sistem hukum, politik hukum.

\section{Pokok Muatan}

A. Pendahuluan 490

B. Pembahasan

1. Eksistensi Peradilan Adat dalam Ketatanegaraan Indonesia

2. Keberlakuan Peradilan Adat

3. Peradilan Adat dalam Diskursus Kuasa Ekonomi Politik 499

C. Penutup 


\section{A. Pendahuluan}

Peradilan adat tak bisa dipisahkan dalam sistem hukum Indonesia. Bekerjanya hukum adat dan institusinya, tak lepas dari kemajuan pengakuan konstitusi, khususnya Pasal 18 B ayat (1) dan ayat (2) serta Pasal 28 I ayat (3) Undang-Undang Dasar Negara Republik Indonesia Tahun 1945 (UUD NRI 1945).

\section{Pasal 18 B ayat (2) UUD NRI 1945}

Negara mengakui dan menghormati satuansatuan pemerintahan daerah yang bersifat khusus atau bersifat istimewa yang diatur dengan undang-undang.

Negara mengakui dan menghormati kesatuan-kesatuan masyarakat hukum adat beserta hak-hak tradisionalnya sepanjang masih hidup dan sesuai dengan perkembangan masyarakat dan prinsip Negara Kesatuan Republik Indonesia, yang diatur dalam undang-undang.

Pasal 28 I ayat (3) UUD 1945

Identitas budaya dan hak masyarakat tradisional dihormati selaras dengan perkembangan zaman dan peradaban.

Pasal 18B ayat (1) dan ayat (2) UUD 1945 menegaskan soal governance, atau ketatapemerintahan serta relasi pengakuan negara terhadap komunitas. ${ }^{1}$ Pemisahan antara Pasal 18B ayat (1) dengan Pasal 18B ayat (2), sebenarnya menarik, karena diperlukan untuk membedakan antara bentuk persekutuan masyarakat (hukum) adat dengan pemerintahan "kerajaan" lama yang masih hidup dan dapat bersifat istimewa. Sedangkan Pasal 28I ayat (3) lebih menempatkannya sebagai penghormatan dan jaminan perlindungan hak asasi manusia, sehingga konstruksi konstitusionalismenya lebih fokus pada politik hak asasi manusia.

Sekalipun demikian, positivisasi pengakuan konstitusional yang bersyarat tersebut memiliki masalah. F. Budi Hardiman (2006: 62) menyebut bahwa pengakuan bersyarat itu memiliki paradigma subjek-sentris, paternalistik, asimetris, dan monologal, sebagaimana tersingkap dalam frasa 'Negara mengakui', 'Negara menghormati', '... sepanjang ... sesuai dengan prinsip NKRI' yang mengandaikan peran besar negara untuk mendefinisikan, mengakui, mengesahkan, melegitimasi eksistensi, sepanjang masyarakat adat mau ditaklukkan di bawah regulasi negara atau dengan kata lain 'dijinakkan'. Paradigma seperti ini tidak sesuai dengan prinsip kesetaraan dan otonomi yang ada dalam Negara demokrasi. ${ }^{2}$

Sekalipun demikian, pengakuan demikian selalu menjadi 'pintu masuk' dalam proses pengakuan secara substantif atas hak-hak masyarakat adat. ${ }^{3}$ Misalnya, upaya mendorong demokrasi dan keadilan dalam pengelolaan sumberdaya alam, ditunjukkan dengan keberadaan Ketetapan MPR No. IX/2001 tentang Pembaruan Agraria dan Pengelolaan Sumberdaya Alam. ${ }^{4}$ Perkembangan politik hukum perlindungan hak-hak masyarakat

Untuk studi lengkap soal 'pengakuan', vide: Rikardo Simarmata, 2006, Pengakuan Hukum terhadap Masyarakat Adat di Indonesia, UNDP, Jakarta.

F. Budi Hardiman, "Posisi Struktural Suku Bangsa dan Hubungan antar Suku Bangsa dalam Kehidupan Kebangsaan dan Kenegaraan di Indonesia (Ditinjau dari Perspektif Filsafat)", dalam Ignas Tri, Hubungan Struktural Masyarakat Adat, Suku Bangsa, Bangsa, dan Negara (Ditinjau dari Perspektif Hak Asasi Manusia), 2006, Komnas HAM, Jakarta.

Dari sisi peristilahan, masyarakat adat dalam teks ini pula mencakup apa yang diistilahkan dengan masyarakat hukum adat. Herlambang P. Wiratraman, et al., 2010, Antara Teks dan Konteks: Dinamika Pengakuan Hukum terhadap Hak Masyarakat Adat atas Sumber Daya Alam di Indonesia, Huma, Jakarta.

4 Prinsip-prinsip mendasar 'pengakuan' negara dalam TAP MPR tersebut, antara lain:

(a) bahwa sumber daya agraria/ sumber daya alam meliputi bumi, air, ruang angkasa dan kekayaan alam yang terkandung di dalamnya sebagai Rahmat Tuhan Yang Maha Esa kepada bangsa Indonesia, merupakan kekayaan nasional yang wajib disyukuri. Oleh karena itu harus dikelola dan dimanfaatkan secara optimal bagi generasi sekarang dan generasi mendatang dalam rangka mewujudkan masyarakat adil dan makmur;

(b) bahwa Majelis Permusyawaratan Rakyat Republik Indonesia mempunyai tugas konstitusional untuk menetapkan arah dan dasar bagi pembangunan nasional yang dapat menjawab berbagai persoalan kemiskinan, ketimpangan dan ketidakadilan sosial-ekonomi rakyat serta kerusakan sumber daya alam;

(c) bahwa pengelolaan sumber daya agraria/sumber daya alam yang berlangsung selama ini telah menimbulkan penurunan kualitas lingkungan, ketimpangan struktur penguasaan pemilikan, penggunaan dan pemanfaatannya serta menimbulkan berbagai konflik;

(d) bahwa peraturan perundangundangan yang berkaitan dengan pengelolaan sumber daya agraria/sumber daya alam saling tumpang tindih dan bertentangan; 
adat dari sudut pandang perdebatan yang terjadi dalam sidang-sidang peradilan, seperti judicial review melalui Mahkamah Konstitusi, penting untuk disimak.

Sebagai contoh kasus review atas penyusunan renstra zonasi wilayah laut, berikut pengelolaannya melanggar hak konstitusional masyarakat adat. Mahkamah Konstitusi menegaskan bahwa pasal 33 UUD NRI 1945 harus memperhatikan hak individu dan hak masyarakat adat secara kolektif (collective rights), sehingga pemberian atau praktek pengkaplingan di laut menjadi inskonstitusional. Begitu juga tafsir dalam putusan Mahkamah Konstitusi yang melarang praktek-praktek pengkaplingan seperti Hak Penguasaan Perairan Pesisir (HP3). Mahkamah Konstitusi dalam konteks itu mengeluarkan dua terobosan, yakni penegasan makna "sebesar-besar kemakmuran rakyat" yang diukurdari empat hal: kemanfaatan sumberdaya alam bagi rakyat, tingkat pemerataan sumberdaya alam bagi rakyat, tingkat partisipasi untuk menentukan sumberdaya alam, dan penghormatan hak rakyat. ${ }^{5}$ Tradisi kebudayaan nelayan, seperti bapongka, menee, panglima laut, sasi, dan lain sebagainya yang ada hubungan erat terkait budaya/tradisi menjadi lebih diakui. Dalam konteks itu, konsepsi 'nelayan tradisional', sekaligus memperkenalkan atau menegaskan hak-hak konstitusionalnya, bagi mereka yang tinggal di pesisir dan pulau-pulau kecil. Misalnya (1) hak untuk melintas, tidak boleh dibatasi melintasi perairan, (2) hak untuk mengelola SDA sesuai budaya dan kearifan, (3) mereka memiliki hak untuk memanfaatkan, dan (4) memanfaatkan hak atas lingkungan yang sehat. ${ }^{6}$
Sekalipun hukumnya menyandarkan rujukan konstitusional untuk pengelolaan sumberdaya alam, dalam Undang-Undang Nomor 1 Tahun 2014, sesungguhnya tak berubah secara substansial atau paradigmanya. Apalagi, kerangka hukum demikian tanpa malu menyebutkan posisi asing untuk eksploitasi sumberdaya alam. Pengakuan atas hak-hak masyarakat adat melalui upaya konstitusi sekalipun, pemberlakuannya sangat bergantung dari situasi tertentu yang mempengaruhinya. Hal yang sama, tatkala memperbincangkan peradilan adat sebagai benteng politik hukum bagi masyarakat adat untuk melindungi hak-haknya, proses politik hukum yang bekerja pula tak berdiri di ruang kosong.

Peradilan adat berinteraksi dalam sistem politik yang menampilkan kuasa ekonomipolitik desentralisasi. Kuasa dalam desentralisasi menguat di tingkat local, dan membentuk karakter bertahannya jaringan oligarki. ${ }^{7}$ Akibatnya, eksploitasi sumberdaya alam menjadi demikian masif nan merusak, dan diperburuk oleh ketatapemerintahan yang belum berubah, birokrasi yang korup dan feodalistik.

Itu sebab, artikel ini berangkat dari asumsi bahwa bekerjanya peradilan adat sangat kuat dipengaruhi bukan hanya sistem sosial budaya kemasyarakatan, melainkan pula sistem ekonomi politik yang bekerja dalam isu hukum dan masyarakatnya. Penjelasan demikian relevan untuk mendiskusikan, bagaimana sesungguhnya politik hukum peradilan adat dalam konteks dua dekade pasca Soeharto? Apa yang berubah, perkembangan maupun tantangan untuk proses pengakuan negara maupun keberlakuannya di tengah masyarakat?

(e) bahwa pengelolaan sumber daya agraria/sumber daya alam yang adil, berkelanjutan, dan ramah lingkunganharus dilakukan dengan cara terkoordinasi, terpadu dan menampung dinamika, aspirasi dan peran serta masyarakat serta menyelesaikan konflik;

(f) bahwa untuk mewujudkan cita-cita luhur bangsa Indonesia sebagaimana tertuang dalam Pembukaan Undang-Undang Dasar Negara Republik Indonesia Tahun 1945, diperlukan komitmen politik yang sungguh-sungguh untuk memberikan dasar dan arah bagi pembaruan agraria dan pengelolaan sumber daya alam yang adil, berkelanjutan dan ramah lingkungan;

Mahkamah Konstitusi melalui putusan Nomor 3/PUU-VIII/2010 tentang Hak Penguasaan Perairan Pesisir (HP3). Lihat Putusan Mahkamah Konstitusi Nomor 3/PUU-VIII/2010 perihal Pengujian Undang-Undang Republik Indonesia Nomor 27 Tahun 2007 tentang Pengelolaan Wilayah Pesisisr dan Pulau-Pulau Kecil terhadap Undang-Undang Dasar Negara Republik Indonesia Tahun 1945.

6 Herlambang P. Wiratraman, et al., 2014, Politik Hukum Nasional terhadap Perlindungan Hukum Masyarakat Hukum Adat, Analisis Harmoni Perundang-undangan Berkaitan Sumberdaya Alam (Studi Kehutanan, Perkebunan, Pesisir dan Kelautan), Laporan Pengkajian Badan Pengkajian Badan Pembinaan Hukum Nasional (BPHN), BPHN, Jakarta.

Vedi R. Hadiz, 2010, Localising Power in Post-Authoritarian Indonesia: A Southeast Asia Perspective, Stanford University Press, Stanford. 


\section{B. Pembahasan}

1. Eksistensi Peradilan Adat dalam Ketatanegaraan Indonesia

Pengakuan keberadaan masyarakat adat (dan hak tradisionalnya) memiliki dinamika dalam sejarah hukum di Indonesia. Sebelum 1945, pemerintah Kolonial Belanda menerapkan politik pluralisme hukum dengan membagi sistem hukum ke dalam tiga stelsel hukum, yaitu: hukum perdata barat, hukum untuk bangsa timur asing, serta hukum adat untuk penduduk pribumi. Kemudian, proses unifikasi hukum diupayakan Pemerintah Indonesia mulai dari perumusannya dalam konstitusi (UUD NRI 1945) sampai pada pemberlakuan UndangUndang Nomor 5 Tahun 1960 tentang Peraturan Dasar Pokok-pokok Agraria (UUPA).

Dalam sidang BPUPKI, 10-17 Juli 1945, Muh. Yamin mengemukakan bahwa ia mengusulkan Undang-Undang Dasar mengubah sifat pemerintahan bawahan memenuhi kemauan zaman baru. Sekalipun demikian, Yamin menegaskan, “.... tetapi yang perlu ditegaskan di sini, yaitu bahwa desa-desa, negeri-negeri, marga-marga dan lainnya tetaplah menjadi kaki Pemerintahan Republik Indonesia." 8

Secara khusus, istilah 'peradilan adat' telah pula diakui keberadaannya sebelum Indonesia merdeka, setidaknya melalui peraturan perundang-undangan masa Pemerintahan Hindia Belanda. Saat itu dikenal lima jenis peradilan, yaitu Peradilan Gubernemen (Gouvernementsrechtspraak), Peradilan Pribumi atau Peradilan Adat (Inheemsche Rechtspraak), Peradilan Swapraja (Zelfbestuurrechtspraak), Peradilan Agama (Godsdienstige Rechtspraak) dan PeradilanDesa (Dorpjustitie). ${ }^{9}$ Keberadaan pengadilan adat telah ada sejak jaman Kolonial Belanda. Pengadilan tersebut diatur dalam pasal 130 Indische Staatsregeling, sebuah peraturan dasar dalam pemerintah Belanda yang menentukan di samping ada pengadilan-pengadilan oleh pemerintah Belanda, diakui dan dibiarkan berlakunya pengadilan-pengadilan asli baik berbentuk pengadilan adat di sebagian daerah yang langsung ada di bawah pemerintah Hindia Belanda dan pengadilan Swapraja. ${ }^{10}$

Diakuinya peradilan untuk orang pribumi, yaitu peradilan adat dan peradilan desa karena Belanda menyadari bahwa mereka tidak bisa menyelesaikan sendiri seluruh persoalan yang dihadapi oleh penduduk Hinda Belanda (Indonesia) sendiri dengan menggunakan peradilan Eropa. Pembagian penggolongan penduduk oleh Belanda dipandang sebagai solusi atas masalah tersebut, oleh sebabnya Pasal 163 Indische Staatsregeling menegaskan golongan penduduk di Hindia Belanda dibagi menjadi tiga yaitu: golongan Penduduk Eropa, golongan Penduduk Timur Asing dan golongan Penduduk Pribumi. Tiap golongan penduduk tersebut menerapkan aturan hukum yang sesuai dengan golongan masing-masing apabila terjadi perkara, kecuali melakukan penundukan diri ke hukum yang digunakan oleh pemerintah Belanda.

Saat itu, Inheemsche Rechtspraak merupakan peradilan yang dilaksanakan oleh para Hakim Eropa dan juga Hakim Indonesia, tidak mengatasnamakan Raja atau Ratu Belanda dan tidak berdasarkan tata hukum Eropa, melainkan didasarkan atas tata hukum adat yang ditetapkan oleh Residen dengan persetujuan Direktur Kehakiman di Batavia. ${ }^{11}$

Kewenangan mengadili dari peradilan ini adalah terhadap orang-orang pribumi yang berdomisili di daerah peradilan, yang dijadikan Tergugat atau Tersangka. Penggugat atau pihak yang menyengketakan boleh saja yang bukan penduduk setempat, termasuk orang Eropa atau non-pribumi yang merasa dirugikan.

Peradilan ini menggunakan hukum acara

\footnotetext{
Risalah Sidang Badan Persiapan Usaha-Usaha Kemerdekaan Indonesia (BPUPKI)-Panitia Persiapan Kemerdekaan Indonesia (PPKI) Sekretariat Negara Republik Indonesia, Jakarta, 1995: 179-180.

Hilman, Hadikusuma, 1989, Peradilan Adat di Indonesia, Miswar, Jakarta.

Tresna, 1978, Peradilan di Indonesia dari Abad Ke Abad, Pradnya Paramita, Jakarta, hlm. 73.

Daerah-daerah dimana dilaksanakan Peradilan Pribumi/Peradilan Adat adalah: Aceh, Tapanuli, Sumatera Barat, Jambi, Palembang, Bengkulu, Riau, Kalimantan, Sulawesi, Manado, Lombok dan Maluku.
} 
atau formal sendiri yang khusus berupa peraturan peradilan dari Residen, misalnya: Peraturan Musapat Aceh Besar dan Singkel (1934), Peraturan Kerapatan Kalimantan Selatan dan Timur (1934), Peraturan Gantarang, Matinggi dan Laikan (Sulawesi Selatan 1933). ${ }^{12}$ Pengakuan terlihat pula dalam Pasal 9 ayat 3 'Kontrak Politik' yang dibuat dengan pemerintah-pemerintah Swapraja dalam Negara Sumatera Timur dahulu, karesidenan Kalimantan Barat dahulu dan Negara Indonesia Timur dahulu (Staatsblad 1939 No. 146, 612 dan 613), pula pasal 9 ayat 3 "Peraturan Swapraja 1938" (Staatsblad 1938 No. 529) yang sekedar mengenai daerah-daerah Swapraja dalam Negara Sumatera Timur dahulu karesidenan Kalimantan Barat dahulu dan Negara Indonesia Timur dahulu yang hubungannya dengan Pemerintah Republik Indonesia diperintahkan oleh yang disebut "Korte Verklaring". ${ }^{13}$

Politik hukum peradilan adat masa kolonial yang demikian, menunjukkan terjadinya proses pengakuan yang sekaligus pengawasan yang harus tunduk dari sistem hukum moderen, khususnya di bawah sistem kolonial pemerintahan Hindia Belanda.

Keberadaan peradilan adat yang demikian, bertahan hingga masa awal kemerdekaan dan masa pemerintahan Soekarno. Sejak itu, dinyatakan bahwa putusan-putusan peradilan formal menjadi salah satu sumber hukum adat dalam kurun Indonesia merdeka. ${ }^{14}$

Di awal tahun 1950an, eksistensi peradilanperadilan di Indonesia mengalami sejumlah penataan dalam rangka unifikasi. Hal tersebut bisa terlihat dari sejumlah ketentuan. Pertama, Undang-Undang tentang Penghapusan PengadilanRaja (Zelfbestuursrechtspraak) di Jawa dan
Sumatera (Lembaran Negara Republik Indonesia Tahun 1947 No. 23) juncto Peraturan Pemerintah Pengganti Undang-undang No. 1 Tahun 1950 tentang Peraturan Daerah Pulihan, setelah diubah dengan Undang-Undang No. 8 Tahun 1950. Kedua, melalui Undang-Undang Darurat Nomor 1 Tahun 1951 tentang Tindakan-Tindakan Sementara untuk Menyelenggarakan Kesatuan Susunan Kekuasaan dan Acara Pengadilan-Pengadilan Sipil (UU Drt No 1 Tahun 1951).

Dalam UU Drt No 1 Tahun 1951, menegaskan dalam pasal 1 ayat (2) bahwa Menteri Kehakiman diberi mandat untuk menghapus secara berangsurangsur dua peradilan, yakni segala Pengadilan Swapraja (Zelfbestuursrechtspraak) dan segala Pengadilan Adat (Inheemse rechtspraak in rechtstreeksbestuurd gebied).${ }^{15}$

Aturan Peralihan dalam Pasal 20 huruf H UU Drt No 1 Tahun 1951, pula mengatur transisi upaya penghapusan tersebut, khususnya terkait kasus-kasus pidana yang sedang ditangani baik oleh pengadilan swapraja maupun pengadilan adat. Berikut kutipan pasal terkait transisi tersebut:

(1) Terhadap segala perkara pidana yang pada saat peraturan ini mulai berlaku telah diputuskan oleh Pengadilan Swapraja atau Pengadilan Adat, maka ketentuan dalam aturan peralihan bab B yuncto ketentuan dalam pasal 5 bab 3 huruf $b$ berlaku juga.

(2) Segala perkara yang pada saat peraturan ini mulai berlaku telah ada pada Pengadilan Swapraja atau Pengadilan Adat - melainkan perkara yang dikecualikan berdasar atas ketentuan dalam pasal 1 ayat (2) bab $\mathrm{a}$ dan $\mathrm{b}$-, dijalankan putusannya atau diteruskan perjalanan putusannya atau dilanjutkan pemeriksaannya dan diputuskan oleh Pengadilan Negeri

\footnotetext{
Hedar Laudjeng, 2003, Mempertimbangkan Peradilan Adat, HuMa, Jakarta.

'Kontrak Politik' tersebut menjadi bagian 'Menimbang' dalam Undang-Undang Darurat Nomor 1 Tahun 1951 tentang Tindakan-Tindakan Sementara untuk Menyelenggarakan Kesatuan Susunan Kekuasaan dan Acara Pengadilan-Pengadilan Sipil.

14 M.B. Hooker, 1978, Adat Law in Modern Indonesia, Oxford University Press, Kuala Lumpur.

15 Pasal 1 ayat (2) UU Drt No 1 Tahun 1951: Pada saat yang berangsur-angsur akan ditentukan oleh Menteri Kehakiman dihapuskan: (a) segala Pengadilan Swapraja (Zelfbestuursrechtspraak) dalam Negara Sumatera Timur dahulu, Karesidenan kalimantan Barat dahulu dan Negara Indonesia Timur dahulu, kecuali peradilan Agama jika peradilan itu menurut hukum yang hidup merupakan satu bagian tersendiri dari peradilan Swapraja; (b) segala Pengadilan Adat (Inheemse rechtspraak in rechtstreeksbestuurd gebied), kecuali peradilan Agama jika peradilan itu menurut hukum yang hidup merupakan satu bagian tersendiri dari peradilan Adat.
} 
yang dimaksudkan dalam pasal 5 bab 3 huruf a, menurut hukum acara yang berlaku untuk Pengadilan Negeri itu.

(3) Untuk dapat melakukan ketentuan dalam bab 1, Pemimpin swapraja dan Pemimpin Pengadilan Adat harus mengirimkan selekas-lekasnya segala perkara tersebut beserta segala surat pemeriksaan sidang dan segala surat pembukti perkara itu kepada Panitera pengadilan Negeri yang dimaksudkan dalam pasal 5 bab 3 huruf a.

(4) Arsip Pengadilan Swapraja dan segala barang bukti yang ada padanya, dan arsip, uang dan barang-barang Pengadilan Adat beserta segala barang bukti yang ada padanya, oleh Pemimpin pengadilan-pengadilan itu harus diserahkan selekas-lekasnya kepada Panitera Pengadilan Negeri yang dimaksudkan dalam pasal 5 bab 3 huruf a.

(5) Kepala alat Penuntutan Umum pada Pengadilan Swapraja harus menyerahkan selekas-lekasnya segala perkara pidana yang ada padanya untuk diperiksa beserta segala barang bukti dan arsip Kantornya, dan Kepala alat Penuntutan Umum pada Pengadilan Adat harus menyerahkan selekasselekasnya segala perkara pidana yang ada padanya untuk diperiksa beserta segala barang bukti, dan arsip, uang dan barang-barang Kantornya, kepada Kepala Kejaksaan Pengadilan Negeri yang dimaksudkan dalam pasal 5 bab 3 huruf a.

Perkembangan unifikasi kedudukan dan hukum acara dalam aturan UU Drt 1951 yang secara berangsur-angsur menghapus keberadaan pengadilan swapraja dan pengadilan adat yang pernah diakui sebelumnya dalam sistem hukum kolonial. Pembatasan atau penghapusan keberadaan pengadilan swapraja dan pengadilan adat semakin kuat dengan lahirnya Undang-Undang No. 19 Tahun 1964 tentang Ketentuan-Ketentuan Pokok Kekuasaan Kehakiman (UU No. 19/1964). Dalam Penjelasan Umum dinyatakan tegas, “...bahwa peradilan adalah peradilan Negara. Dengan demikian tidak ada tempat bagi peradilan swapraja atau peradilan Adat. Apabila peradilan-peradilan itu masih ada, maka selekas mungkin mereka akan dihapuskan, seperti yang secara berangsurangsur telah dilakukan. Ketentuan itu tidaklah bermaksud untuk mengingkari hukum tidak tertulis yang disebut hukum adat. melainkan hanya akan mengalihkan perkembangan dan penerapan hukum itu kepada Pengadilan-pengadilan Negara." Selain itu, Penjelasan Pasal 1 UU No. 19/1964 pula menyatakan, "Tidak ada tempat bagi peradilan Swapraja yang bersifat faodalistis, atau peradilan Adat yang dilakukan bukan alat perlengkapan Negara."

Kebijakan penghapusan peradilan adat tersebut diikuti di masa Soeharto, melalui UndangUndang Nomor 14 Tahun 1970 tentang KetentuanKetentuan Pokok Kekuasaan Kehakiman. Hal ini diatur dalam bagian Penutup UU tersebut, "Penghapusan Pengadilan Adat dan Swapraja dilakukan oleh Pemerintah". Dalam Penjelasan Umumnya, dinyatakan bahwa penghapusan tersebut “...sekali-kali tidak bermaksud untuk mengingkari hukum tidak tertulis, melainkan hanya akan mengalihkan perkembangan dan penerapan hukum itu kepada Peradilan-peradilan Negara." Sekalipun demikian, dengan undang-undang itu, praktis, yang tersisa hanya peradilan formal.

Sekalipun demikian, kebijakan tersebut lebih 'kebijakan di atas kertas', karena faktanya pengadilan adat tak mudah hapus begitu saja. Pembatasan atau bahkan penghapusan dalam konstruksi hukum tertulis negara berbeda dengan kenyataan di lapangan yang menunjukkan eksistensi peradilan itu masih ada dan masih hidup. Ada atau tiadanya pengakuan (negara atau hukum nasional), sesungguhnya eksistensi peradilan adat di Indonesia telah berlangsung lama, dipertahankan secara turun temurun oleh komunitas lokal dan atau masyarakat adat. Hukum dan masyarakatnya, telah menyatu, mengakar, dan tak mudah terpisahkan sejak sebelum republik lahir.

Dalam konteks ketatanegaraan Indonesia, melalui sejumlah peraturan perundang-undangan, Pemerintah Daerah pula memberikan 'pengakuan' 
hukum. Misalnya, di Tanah Batak khususnya di Tapanuli telah diterbitkan Peraturan Daerah Nomor 10 Tahun 1990 tentang Lembaga Adat Dalihan $\mathrm{Na}$ Tolu. Perda lembaga adat yang dibentuk Pemda Tingkat II (Kabupaten), sebagai lembaga musyawarah mengikutsertakan para penatua adat yang benar-benar memahami, menguasai dan menghayati adat istiadat di lingkungannya. (Pasal 5 dan 8). Keberadaan lembaga adat Dalihan $\mathrm{Na}$ Tolu diharapkan dapat memberikan solusi terkait konflik yang timbul di masyarakat Adat Tapanuli. Di Kalimantan, ditemukan sejumlah peraturan perundang-undangan yang memberikan pengakuan atas eksistensi itu, seperti pengukuhan lembaga Kedamangan, melalui Peraturan Daerah Provinsi Kalimantan Tengah Nomor 14 Tahun 1998. Selain itu, disusul dengan dengan berbagai peraturan daerah tingkat kabupaten, yaitu Peraturan Daerah Kabupaten Barito Selatan Nomor 17 Tahun 2000; Peraturan Daerah Kabupaten Kapuas Nomor 5 Tahun 2001; dan Peeraturan Daerah Kabupaten Kotawaringin Timur Nomor 15 Tahun 2001. ${ }^{16}$

Pasca Suharto, situasi 'pengakuan daerah' (pengakuan melalui hukum pemerintah daerah) tersebut berlanjut dan kian meluas. ${ }^{17}$ Di Papua salah satu contohnya, yang dulu pernah dihapus, kini lahir Peraturan Daerah Khusus Papua Nomor 20 Tahun 2008 tentang Peradilan Adat di Papua. Peradilan adat dalam Perda ini (sebagai tindak lanjut berlakunya UU Otonomi Khusus Papua) adalah peradilan adat pada kesatuan masyarakat hukum adat, bukan tipologi peradilan adat (inheemsche rechtspraak) yang dihapus berdasar UU Drt 1951. Konsep peradilan adat dalam UU Otonomi Khusus Papua dan Perdasus Nomor 20 Tahun 2008 lebih mirip peradilan desa (Dorpjustitie).
Begitu pula penegasan soal adat Dayak kembali diatur melalui Peraturan Daerah Provinsi Kalimantan Tengah Nomor 16 tahun 2008 tentang Kelembagaan Adat Dayak di Kalimantan Tengah. Pula aturan yang sifatnya 'memandu' peradilan adat melalui Peraturan Gubernur Sulawesi Tengah Nomor 42 tahun 2013 tentang Pedoman Peradilan Adat di Sulawesi Tengah. ${ }^{18}$

Di tengah keragaman pengakuan hukum tersebut atas peradilan adat, pertanyaan relevan dalam konteks ketatanegaraan, sekaligus dalam sistem hukum Indonesia, adalah sejauh mana hubungan antara hukum negara dengan hukum adat dalam konteks keberlakuan (gelding atau geltung) peradilan adatnya?

Banyak dijumpai bahwa yurisdiksi peradilan adat memiliki karakter tersendiri yang membedakannya dengan peradilan negara, karena peradilan adat bisa mencakup publik, privat, dan atau kombinasi keduanya dalam satu persidangan. Dalam prakteknya, bisa berlangsung sangat informal, cukup dengan mekanisme mediasi, dengan kemungkinan ruang negosiasi atas prosesnya. ${ }^{19}$ Itu sebab, mendefinisikan atau bahkan mendeterminasi yuridiksi peradilan adat, khususnya menyangkut urusan privat atau publik, sungguh bukan semata hal yang tak mudah, atau bahkan tidak mungkin atau pula berbahaya dalam arti bisa mengubur eksistensi peradilan adat itu sendiri. Peradilan adat, yang mendayagunakan hukum dan atau sistem hukum adat, sesungguhnya memiliki logika sistem dan prinsip tersendiri. ${ }^{20}$

Keberadaan masyarakat adat dan hak tradisionalnya, termasuk pula keberlakuan peradilan adat, menjadi dilematis. Pada satu sisi karena membutuhkan positivisasi (pengakuan hukum

\footnotetext{
16 Abdurrahman, 2002, "Peradilan Adat dan Lembaga Adat dalam Sistem Peradilan Indonesia", makalah, disampaikan dalam Sarasehan Peradilan Adat Kongres Aman II, Mataram, 20 September 2002.

17 Yance Arizona, 2012, "Kedudukan Peradilan Adat dalam Sistem Hukum Nasional", Makalah, disampaikan pada Diskusi tentang Memperkuat Peradilan Adat di Kalimantan Tengah untuk Penguatan Akses terhadap Keadilan, Selasa, 11 Juni 2013. Makalah ini merupakan pembaruan (update) dari makalah "Peradilan Adat: Sejarah Pengaturan dan Peluang Penguatannya" yang disampaikan pada Diskusi Terbatas Memperkuat Peradilan Adat di Sulawesi Tengah untuk Penguatan Akses terhadap Keadilan, Palu, 28 September 2012.

18 Herlambang P. Wiratraman, et al., 2013, Peluang dan Tantangan Peradilan Adat dalam Sistem Hukum Indonesia: Studi Kasus Peradilan Adat yang 'Melibatkan Pihak Luar', Laporan Pengkajian Badan Pengkajian Badan Pembinaan Hukum Nasional (BPHN), BPHN, Jakarta.

9 Ibid.

20 Herlambang P. Wiratraman, et al., 2013, Loc.cit.
} 
negara), maka keberadaan dan hak tradisionalnya hanya akan diakui apabila diatur di dalam hukum tertulis yang dibuat oleh institusi negara. Secara a contrario, dapat dikatakan bahwa, jika tidak diakui secara hukum maka eksistensi peradilan adat itu dianggap lenyap atau tidak ada. ${ }^{21}$ Padahal keberadaan masyarakat adat dan hak tradisionalnya sebagaimana hak asasi yang lain adalah hak yang melekat pada diri masyarakat adat.

Dengan penjelasan di atas, elemen yang mendasar sifatnya soal "sumber otoritas" penyelenggaraan peradilan adat, yang memungkinkan tiga variannya: (1) sumber otoritas penyelenggaraan peradilan adat berasal dari sistem hukum lokal adat setempat, dalam arti ada penegasan dari dan oleh struktur otoritatif di level masyarakat adat; (2) sumber otoritas penyelenggaraan peradilan adat berasal dari non-sistem hukum lokal adat setempat, yang bisa berasal dari pemerintah daerah (Gubernur, Bupati, Kepala Desa, dll.). (3) ada kemungkinan, sumber otoritasnya berasal dari kombinasi keduanya, melalui ruang dialog tertentu yang melahirkan persepakatan soal penyelenggaraan peradilan adat tertentu. Hal ini berbasis pada riset BPHN yang mencoba membedahkan dari sisi bagaimana peradilan adat berhubungan dengan kasus-kasus yang melibatkan pihak luar. ${ }^{22}$

\section{Keberlakuan Peradilan Adat}

Aliansi Masyarakat Adat Nusantara telah mempublikasikan sejumlah pemikiran melalui buku 'Sistem Peradilan Adat dan Lokal di Indonesia, Peluang dan Tantangan' (AMAN, 2003). Salah satu dalam kajian itu, menegaskan ada keinginan perlunya memperluas dan memperkuat jaminan penyelenggaraan peradilan adat dalam konteks sistem hukum Indonesia.

Begitu juga, dalam konteks kelembagaan negara yang menjalankan fungsi kekuasaan yudisial, seperti Mahkamah Agung Republik Indonesia, telah mencanangkan sejumlah program pembaruan peradilan dalam Cetak Biru 2010-2035. Sayangnya, dokumen tersebut kurang memberikan perhatian terhadap relasi kekuasaan kehakiman dengan peradilan adat, atau sama sekali tidak ada. Sekalipun demikian, kini Mahkamah Agung telah membuka ruang untuk menjajaki dialog untuk mendiskusikan soal peradilan adat, sebagaimana diinisiasi bersama antara Perkumpulan HuMa dengan Badan Penelitian dan Pengembangan Mahkamah Agung, di Royal Kuningan, 10 Oktober 2013. ${ }^{23}$ Dalam catatan riset BPHN, ada beberapa alasan perlunya didorong proses penyelesaian sengketa non-litigasi melalui peradilan adat dalam penyelesaian sengketa. Pertama, di Indonesia tata cara penyelesaian sengketa damai telah lama dan biasa dipakai oleh masyarakat Indonesia. Beberapa studi juga menunjukkan hal tersebut. ${ }^{24}$ Penyebabnya, antara lain: ${ }^{25}$

(a) Terbatasnya akses masyarakat terhadap sistem hukum formal yang ada;

(b) Masyarakat tradisional di daerah terisolasi pada dasarnya masih memiliki tradisi hukum yang kuat berdasarkan hukum tradisionalnya dalam memecahkan permasalahan hukum yang terjadi. Hal ini merupakan realitas dimana tradisi atau custom (kebiasaan) masih berlaku di banyak tempat. Ini juga merupakan realitas dimana perubahan masyarakat

21 Bernadinus Steny, "Politik Pengakuan Masyarakat Adat: dari Warisan Kolonial Hingga Negara Merdeka”, Jurnal Jentera Edisi Lingkungan, 2009.

22 Herlambang P. Wiratraman, et al., Op.cit.

23 Sebagai contoh, pandangan hakim dalam presentasi soal relasi tersebut. Vide: Lilik Mulyadi, 2013, "Hukum dan Putusan Adat dalam Peradilan Negara", Makalah, untuk Dialog Nasional Bersama Perkumpulan HuMa dan Mahkamah Agung, Royal Kuningan, 10 Oktober 2013.

24 Ahmadi Hasan, 2007, Penyelesaian Sengketa Hukum Berdasarkan Adat Badamai Pada Masyarakat Banjar dalam Kerangka Sistem Hukum Nasional, Disertasi, Program Doktor Ilmu Hukum Pasasarjana Fakultas Hukum Universitas Islam Indonesia, Yogyakarta. Lihat juga Muhammad Koesnoe, "Musyawarah”, dalam Miriam Budiardjo, 1971, Masalah Kenegaraan, tanpa penerbit, Jakarta, hlm. 551. Dominikus Rato, 2013, "Prinsip, Mekanisme dan Praktek Peradilan Adat dalam Menangani Kasus Hukum dengan Pihak Lain”, Makalah, Focus Group Discussion, BPHN, Jakarta.

25 Sinclair Dinnen, Interfaces Between Formal and Informal Justice Sistem To Strengthen Access to Justice By Disadvantaged Sistem, Makalah disampaikan dalam Practice In Action Workshop UNDP Asia- Pasific Rights and Justice Initiative, Ahungala Sri Lanka, 19-21 November 2003 sebagaimana dikutip Eva Achjani Zulfa, "Keadilan Restoratif dan Revitalisasi Lembaga Adat Di Indonesia", Jurnal Kriminologi Indonesia, Vol. 6, No.II, Agustus 2010, hlm. 182-203. 
kadangkala terbentur batas wilayah, dan bahwa hal ini juga merupakan kenyataan dimana terdapat daerahdaerah yang masih 'steril' atau belum tersentuh dengan keberlakukan sistem hukum formal.

(c) Tipe pemecahan masalah yang ditawarkan sistem hukum formal terkadang memperoleh pandangan yang berbeda dan dianggap kurang memadai dan kurang memenuhi rasa keadilan masyarakat yang masih memegang tradisi hukum mereka sendiri;

(d) Kurang memadainya infrastruktur dan sumberdaya yang dimiliki oleh sistem hukum formal menyebabkan kurangnya daya adaptasi dalam menyerap kebutuhan rasa keadilan masyarakat setempa.

Kedua, pada sebagian besar masyarakat Indonesia terdapat kecenderungan menyelesaikan sengketa dengan cara damai. Cara ini diakui efektif dalam menyelesaikan pertikaian atau persengketaan. Sekaligus mampu menghilangkan perasaan dendam ${ }^{26}$, serta berperan menciptakan keamanan ketertiban dan perdamaian. Ketiga, keberadaan peradilan adat menjadi semakin penting ditengah situasi negara yang belum sepenuhnya mampu menyediakan layanan penyelesaian perkara melalui jalur formal sampai ke desa-desa terpencil. Selain itu, kapasitas peradilan formal yang juga berat karena terjadi penumpukan perkara yang yang sangat serius. Sebagai catatan, bila dilihat pada institusi tertinggi peradilan negara, data Yayasan Lembaga Hukum Indonesia (YLBHI) menunjukkan bahwa "setiap tahun ada 13 ribu perkara yang masuk ke Mahkamah Agung. Jumlah sebanyak itu harus diselesaikan oleh 54 Hakim Agung yang selalu menyisakan 8 ribu kasus tiap akhir tahun". ${ }^{27}$ Tentunya, beban tumpukan kasus demikian berkonsekuensi atas upaya akses keadilan bagi publik. Atas dasar itu, penting untuk mempertimbangkan keberlakuan peradilan di tingkat lokal yang memberi pemaknaan sosial lebih dan menguatkan kearifan-kearifan lokal, seperti sejumlah contoh yang dikutip dari kajian SAJI, yakni tradisi penyelesaian konflik di komunitas Dalihan $\mathrm{Na}$ Tolu (Tapanuli), Rumah Betang (Kalimantan Tengah), Menyama Braya (Bali), Saling Jot dan Saling Pelarangan (NTB), atau Peradilan Adat Clan Selupu Lebong (Bengkulu). ${ }^{28}$

Menariknya, salah satu faktor penting dalam mendiskusikan keberlakuan peradilan adat adalah sejauh mana peradilan adat tersebut dipatuhi para pihakyang sedang berkonflik.Darisudut keberlakuan hukum, apakah para pihak mematuhinya dalam konteks bekerjanya peradilan adat. Secara sosiologi, kajian-kajian mengenai kepatuhan hukum pada dasarnya melibatkan dua variabel, masing-masing adalah hukum dan manusia yang menjadi objek pengaturan hukum tersebut. Kepatuhan terhadap hukum tidak hanya dilihat sebagai fungsi peraturan hukum, melainkan juga fungsi manusia yang menjadi sasaran pengaturan. Kepatuhan hukum tidak hanya dijelaskan dari kehadiran hukum semata, melainkan juga dari kesediaan manusia untuk mematuhinya. ${ }^{29}$ Bila posisi hukum yang dimaksud adalah hukum adat dan mekanismenya adalah peradilan adat, apakah posisi manusiamanusia yang diidentifikasi kepatuhannya menjadi problematis posisinya, karena satu menjadi bagian dari masyarakat adat, dan di sisi lain ada pula yang tidak terkait atau bukan bagian dari masyarakat adat (pihak luar).

Keberlakuan hukum tersebut dalam konteks bekerjanya peradilan adat sangat berkaitan dengan

26 Ahmadi Hasan, 2007, "Penyelesaian Sengketa Melalui Upaya (Non Ligitasi) Menurut Peraturan Perundang-Undangan", Jurnal AL-BANJARI, Vol. 5, No. 9, Januari-Juni 2007.

27 Detik News, “Tunggakan 8 Ribu Perkara Tiap Tahun Jadi Tantangan Ketua MA Baru”, http://news.detik.com/read/2012/02/06/190613/1835 694/10/tunggakan-8-ribu-perkara- tiap-tahun-jadi-tantangan-ketua-ma-baru?nd992203605, diakses 10 Agustus 2018. Lihat juga catatan dari SAJI Project, Pedoman Peradilan Adat Sulawesi Tengah, 2013.

28 Ibid.

29 Satjipto Rahardjo, 2010, Sosiologi Hukum Perkembangan Metode dan Pilihan Masalah, Genta Publishing, Yogyakarta. Satjipto Rahardjo, "Hukum Adat dalam Negara Kesatuan Republik Indonesia (Perspektif Sosiologi Hukum)", dalam Hilmi Rosyida dan Bisariyadi, 2005, Inventarisasi dan Perlindungan Hak Masyarakat Hukum Adat. Komnas HAM, Mahkamah Konstitusi RI, dan Departemen Dalam Negeri, Jakarta. 
bukan semata soal hukum dan manusianya, melainkan pula pertimbangan soal ekonomi, politik dan budaya, dan sistem yang melatari situasinya.

Misalnya dalam konteks peradilan adat yang berkaitan dengan soal eksploitasi sumberdaya alam, tambang, kelapa sawit, atau pelibatan permodalan/ investasi besar, kecenderungannya adalah 'ketidakpatuhan hukum' atas berlakunya hukum adat dan peradilan adatnya. Ada sejumlah kasuskasus konflik agraria dan sumberdaya alam yang sama sekali tak bisa terselesaikan secara hukum adat atau melalui peradilan adat, sebagaimana kita saksikan atas kasus Tambang Mangan di Manggarai, atau kasus Tambang Semen di komunitas Samin.

Oleh sebab itu, keberlakuan peradilan adat sesungguhnya lebih mengedepankan harmoni, terutama penciptaan penerimaan yang lebih mengakomodasikan kebutuhan para pihak'. Karakter harmoni, mengutip Slaats dan Portier dari Simarmata (2013) menyatakan, “... Di mata anggota masyarakat adat, signifikasi proses penanganan sengketa bukan terletak pada isi putusan melainkan pada proses menemukan solusi yang bisa diterima oleh para pihak yang bersengketa dan yang memulihkan harmoni atau menciptakan keseimbangan baru dalam relasi sosial antar anggota komunitas' ${ }^{30}$

Selain soal harmoni sebagai suatu proses mengembangkan keberlakuannya, penting juga untuk memberi perhatian atas prinsip-prinsip mendasar terselenggaranya peradilan adat, yang sama sekali tak boleh diabaikan dalam proses penyelenggaraannya, sebagaimana dalam kajian BPHN. ${ }^{31}$

Prinsip tersebut terdiri dari tiga: prinsip kearifan lokal, keadilan sosial, dan hak asasi manusia. Pertama, prinsip kearifan lokal. Prinsip ini melandaskan penyelenggaraannya atas dasar tradisi yang telah dipertahankan dan dapat diterima luas di tengah masyarakat adat itu, secara turun temurun. Kearifan lokal dikenali sebagai bagian kehidupan masyarakat yang sangat penting sebagai landasan interaksi sosial sekaligus penanda moralitas yang diakui sebagai keyakinan setempat. Contohnya, kearifan untuk 'mengistirahatkan tanah' di masyarakat adat Kaili Sulawesi Tengah, atau kearifan yang sama di Desa Bika, yang mayoritas warganya berasal dari suku Dayak Kantuk. Namun, tanah yang 'diistirahatkan' tersebut dianggap lahan tidur, sehingga dalam prakteknya seringkali dijual atau dilepas untuk perusahaan-perusahaan.

Kedua, prinsip keadilan sosial. Prinsip ini mengedepankan terwujudnya rasa keadilan yang dirasakan sangat penting di tengah masyarakat keberlakuannya, atau suatu yang memiliki kebermaknaan sosial (social significance). Keadilan sosial ini memandang sisi 'adil' dari perspektif tak semata 'hukum' dan 'penegakan hukum'nya, melainkan pula jangkauan rasa keadilan bagi masyarakat luas, yang pertimbangannya mencerminkan cita-cita sosial.

Ketiga, prinsip hak asasi manusia (HAM). Prinsip ini meliputi cara pandang universalitas hak asasi manusia, non-diskriminasi, kesetaraan, pemartabatan manusia, tidak memisahkan hak asasi yang satu dengan hak asasi lainnya (indivisibel dan interdependensi), serta menempatkan tanggung jawab negara dalam upaya memajukan dan melindungi hak asasi manusia. Tentu, ukurannya menjadi tak semata hukum hak asasi manusia sebagai telah diundangkan dalam peraturan atau hukum negara, maupun hukum internasional, melainkan lebih mengedepankan pada falsafah moralitas hak.

\section{Peradilan Adat dalam Diskursus Kuasa Ekonomi Politik ${ }^{32}$}

Konteks pembangunan hukum masa reformasi, wacana peradilan adat kembali 'meng-

\footnotetext{
30 Slaat dan Portier, 1992, dari Rikardo Simarmata, 2013. "Merumuskan Peradilan Adat dalam Sistem Peradilan Nasional”, Makalah, disampaikan dalam Dialog Nasional Bersama Perkumpulan HuMa dan Mahkamah Agung, Royal Kuningan, 10 Oktober 2013.

31 Herlambang P. Wiratraman, et al., Op.cit.

32 Bagian ini diadaptasi dari tulisan pendek, Herlambang P. Wiratraman, 2013, Peradilan Adat dan Utopia Kekuasaan? Bulletin HuMa, Jakarta. Dikembangkan dengan pendekatan Ungerian. Vide: Unger, Roberto Mangabeira. 1976. Law and Modern Society: Toward Criticism of Social Theory. University of Michigan, Free Press; Unger, Roberto Mangabeira. 1996. What Should Legal Analysis Become? London and New York: Verso.
} 
hangat'. Bergeliatnya komunitas akademik, orgaisasi non pemerintah dan bahkan lembaga donor serta pemerintah sendiri mulai memberikan perhatian atas keberadaan peradilan adat. Suatu perkembangan menarik, dan memang sudah sewajarnya dalam konteks Indonesia yang majemuk, baik dari sisi sosial, hukum dan kelembagaan hukum lokal, termasuk peradilan adat, merupakan upaya menguatkan kehidupan kemasyarakatan yang berbasis pada nilai-nilai lokal menjadi perlu.

Masalahnya, ia hadir dengan sejumlah konteks politik hukum. Konteks itu, antara lain, pertama, bergulirnya draft Rancangan Undang-Undang Pengakuan dan Perlindungan Hak atas Masyarakat Hukum Adat (RUU PPHMA) yang kini masuk ke ruang politik legislasi di parlemen. Peradilan adat, tentunya, menjadi satu topik pembahasan cukup sengit mengingat isunya akan menjangkau wilayah kekuasaan politik otoritas penyelesaian atas kasuskasus yang berdimensi politik ekonomi sangat kuat, utamanya mencakup isu sumberdaya alam dan pemosisian kekuasaan politik formal negara.

Kedua, sekalipun telah menyejarah dalam konteks sistem politik lokal, memperlihatkan kian maraknya peradilan adat dipraktekkan untuk merespon relasi kewenangannya yang berurusan dengan kasus-kasus hukum yang melibatkan 'pihak luar'. Ada sejumlah kasus yang cukup menarik sekaligus kontroversial dari sudut pandang sejauh mana otoritas peradilan adat bersinggungan dengan mekanisme formal peradilan negara. Selain menjadi lebih terkenal, kasusnya itu sendiri melibatkan tokoh masyarakat, pejabat atau aparat negara, ilmuwan, atau orang-orang yang berstrata sosial lebih tinggi. Seperti kasus persidangan bagi dosen Thamrin Amal Tamagola melalui 'peradilan adat'. ${ }^{33}$

Ketiga, posisi peradilan formal negara yang tidak cukup kuat nan efektif dalam menjangkau secara lebih berkeadilan dan menyeluruh serta memberikan kemanfaatan secara sosial-politik.
Tumpukan kasus di Mahkamah Agung, serta tidak kokohnya independensi peradilan di tingkat daerah, panjang prosesnya dan berbiaya mahal, apalagi masih begitu mudahnya ditemui praktik suap dan mafia yang melahirkan perluasan ketidakpercayaan publik. ${ }^{34}$ Sekalipun dua dekade reformasi hukum berlangsung, pengadilan belum banyak alami perubahan, khususnya tatkala menjadi mata rantai tak terpisahkan dengan bekerjanya mafioso dan makelar kasus hukum, yang jamak diketahui publik begitu mudahnya memperdagangkan putusan hakim. Agenda pembersihan mafia hukum di Mahkamah Agung adalah mendasar karena ada di pucuk institusi peradilan, dilanjutkan di jajaran lebih rendah, sayangnya agenda tersebut belumlah selesai. ${ }^{35}$

Oleh sebab itu, penting untuk memahami bahwa bekerjanya sebuah peradilan, khususnya peradilan adat yang dekat dengan komunitas sosial dalam konteks politik ekonominya. Tentu, basis pemikirannya berkaitan dengan bahwa hukum sendiri, tak terkecuali hukum adat dan institusi peradilan adatnya, tumbuh dan berkembang di tengah masyarakat, termasuk berada dalam pusaran kekuasaan ekonomi dan politik yang berlangsung di dalam kehidupan masyarakatnya. Acapkali, hukum dalam bentuk aturan-aturan (formal ataupun yang non-formal) merupakan refleksi dari kontestasi kepentingan yang melahirkan rumusan-rumusan yang menjelaskan kehendak dan perjumpaan kepentingan politik yang terepresentasi 'secara formal' atau 'terlegitimasi sosial-politik'. Tentunya, keberadaan aturan demikian bisa merupakan sejumlah kehendak dan ekspresi, baik itu berupa keadilan, kearifan sosial-lokal, imajinasi ketertiban dan harmoni masyarakat, kepastian hukum, kemanfaatan sosial-ekonomi, bangunan politik, dan resolusi konflik atas pertumbukan dan atau persinggungan kepentingan.

Peradilan, dalam pandangan yang demikian,

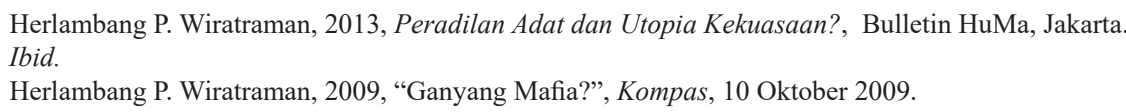


merupakan mekanisme pemenuhan, campur tangan dan atau pemaksaan atas upaya peneguhan kehendak dan ekspresi. Lantas, bagaimana membaca perkembangan situasi 'kebangkitan' diskursus peradilan adat di Indonesia yang kian mengemuka belakangan ini, serta bagaimana menjelaskan dari sudut pandang ekonomi politik peradilan adat dalam konteks sistem hukum nasional Indonesia. Peradilan adat sebagai mekanisme alternatif yang diharapkan lebih diterima nan efektif dibandingkan mekanisme peradilan formal negara. Apalagi, akan banyak memberikan manfaat tatkala kasus yang sedang dihadapi merupakan kasus-kasus yang lokal yang berkaitan dengan pelanggaran hukum adat tertentu.

Hal demikian, dimungkinkan karena mekanisme peradilan adat yang memungkinkan memberikan 'ruang terdekat' secara sosial-politik untuk penyelesaian dan/atau penuntasan kehendak dan ekspresi masyarakat. Peradilan adat secara sosial mampu memberikan rasa keadilan yang substantif, ketenangan, kedamaian, ketertiban. Proses itu, tentu akan lebih memiliki efektifitas fungsinya bila tersemat kekuasaan yang melegitimasinya, baik itu dalam bentuk yang paling formal, misal pengakuan negara melalui peraturan di daerah (Peraturan Daerah, Surat Keputusan, Perjanjian, dan lainnya), hingga yang sifatnya tak tertulis namun cukup baik diketahui luas (semacam struktur maupun sistem sosial budaya lokal yang turun temurun dipertahankan), relasi kuasa politik yang kuat (seperti pengakuan adanya eksistensi komunitas dengan tetua adatnya), hingga dimensi legitimasi ekonomi (memberikan kontribusi pendanaan atas penyelenggaraan peradilan, pembayaran pada hakim, dan biaya lain yang diperlukan).

Sekalipun demikian, ada pula kemungkinan peradilan tersebut memiliki kedigdayaan [baca: daya penggentar yang memberikan rasa takut untuk kepatuhan tertentu] karena keberadaan instrumentasi penegak hukum adat, seperti 'satgas adat' (atau semacam keamanan dari pihak masyarakat adat,) atau kelompok khusus dalam komunitas adat yang setiap waktu bisa dikerahkan merepresi atau memaksakan tindakan 'atas nama adat'.

Dengan mengetengahkan mekanisme alternatif yang berupa peradilan adat dengan keragaman semacamitu,makaproses[ber]hukumdanpenegakan hukumnya tak terlepas dengan konteks politik yang ada. Eksistensi peradilan adat mengalami pergeseran dan berbeda posisi kebermaknaan sosialnya, dari masa otoritarian militer Soeharto, hingga pasca kejatuhannya, menjadi lebih kuat posisi hukum dan sosiologisnya. Peradilan adat pasca Soeharto hadir dengan konteks politik desentralisasi yang sesungguhnya memperlihatkan adanya perpindahan model relasi yang lebih berkaitan dengan modal dan sumberdaya yang lebih bertumpu di daerah ('shifting capital'), bukan semata perpindahan otoritas legitimasi politik pusat-daerah ('shifting authority'). Dengan model relasi yang demikian, tidak begitu mengherankan bila muncul kekuatan politik ekonomi yang demikian kuat dan meluas di daerah, dengan kepentingan yang demikian korup serta menguras sumberdaya alam secara masif untuk kepentingan aliansi kelompok kepentingan itu. Kekuatan ini, sebutlah saja sebagai aliansi predatoris, kelompok oligarki yang menguasai secara dominan posisi dan kepentingan ekonomi politik. Kekuatan aliansi predatoris yang demikian begitu mudah ditemukan di berbagai daerah, apalagi konteks politik elektoral di level lokal kerap disertai dengan pengorganisasian preman atau gangsters ('privatized gangsters') untuk merawat kepentingan dan kekuasaan aliansi tersebut.

Desentralisasi, pada gilirannya, menghadirkan adanya kemungkinan situasi dimana komunitas adat dan institusi peradilan adat akan bersinggungan realitas tidak tahannya godaan politik kekuasaan dalam konteks bekerjanya aliansi predatoris tersebut. Bila hal tersebut terjadi, maka tidak mengherankan bila peradilan adat menjadi lemah dan dilemahkan posisinya. Peradilan adat dalam konteks tersebut sesungguhnya secara kelembagaan adat justru mewakili kepentingan elit-elit yang berafiliasi dengan aliansi predatoris tersebut.

Peradilan adat, sebagai instrumentasi hukum 
yang mekanisme bekerjanya pula berinteraksi dengan situasi tersebut, maka peradilan-peradilan adat tersebut justru melayani kekuasaan formal yang sebenarnya dilahirkan dari instrumentasi demokrasi elektoral yang sarat dengan bayangbayang kekuatan oligarkis. Tidaklah mengherankan, sebagaimana terjadi dalam kasus sidang eradilan adat Thamrin Amal Tamagola, pada akhirnya banyak fakta ditemukan bekerjanya peradilan adat justru memelihara atau merawat kepentingan tersebut, menampilkan sosok kelas sosial tertentu yang secara eksesif hadir dengan supremasi etnisitas tertentu.

Politik hukum peradilan adat dalam konteks politik-ekonomi yang dideskripsikan di atas, bukan tak mungkin menjadikannya suatu tatanan hukum atau mekanisme politik hukum yang bercorak represif, bukan responsif terhadap kehendak dan ekspresi yang berdimensi keadilan sosial dan jaminan perlindungan hak asasi manusia.

Konteks politik ekonomi, memungkinkan praktik peradilan adat pula memperlihatkan konfigurasi sistem dan relasi politik kekuasaan di level lokal. Hukum, tak saja hukum negara, tetapi juga hukum lokal, sangat berpotensi mewakili kepentingan kelas elit tertentu. Salah satu penandanya adalah diam atau tak berkutiknya mekanisme peradilan adat untuk menyidangkan kasus-kasus yang berhadapan dengan kekuatan ekonomi perkebunan ekstraktif atau perluasanperluasan areal pertambangan.

Penjelasan kritis, mengapa peradilan adat yang diselenggarakan oleh suatu komunitas masyarakat tampil begitu perkasa dan digdaya di saat menyidangkan kasus pernyataan yang dianggap suatu penghinaan atas komunitas adat tertentu, sementara persoalan penghancuran sumberdaya alam hutan secara sistematik, atau bahkan jelasjelas menghancurkan sistem sosial budaya setempat yang berdampak terhadap komunitas adat tertentu, justru fungsi dan institusi peradilan adat tersebut mendiamkan saja dan terkesan sama sekali tak berkutik?

Mengapa pula Gubernur atau kepala daerah dalam kebijakannya tidak mengupayakan penguatan sidang-sidang adat lokal yang berkaitan dengan persoalan eksploitasi sumberdaya alam atau penghancuran lingkungan karena penyingkiran hakhak masyarakat adat? Padahal, dalam kasus-kasus tersebut memperlihatkan betapa masyarakat adat berupaya menjaga dan merawat hak-hak masyarakat adat dan lingkungan, sebagaimana terjadi dalam kasus peradilan adat yang menyidangkan kasus penebangan dan pencurian kayu di hutan adat Kulawi di Boya Marena, Sulawesi Tengah (2010), kasus peradilan adat Dayak Limbai Ketemenggungan Pelaik Keruap menghadapi PT. Mekanika Utama (perusahaan tambang batu bara) $(2009)^{36}$, dan kasus Peradilan Adat Dayak Jalai Kendawangan, Silat Hulu Ketapang, di Kalimantan Barat yang menghadapi perusahaan Bangun Nusa Mandiri (kasus Vitalis Andi dan Japin) (2009).

Penyingkapan kepentingan bekerjanya peradilan adat dalam diskursus kuasa ekonomi politik menjadi penting untuk tidak secara mudah memberi ruang legitimasi kuasa oligarki melalui aliansi predatoris dalam konteks desentralisasi di Indonesia.

\section{Penutup}

Diskusi tentang soal keberadaan peradilan adat, pada akhirnya harus mempertimbangkan konteks politik hukumnya. Politik hukum yang dimaksudkan di sini adalah bahwa peradilan adat dihadapkan pada sejumlah tantangan. Secara paradigmatik, kebijakan atas konflik sumberdaya alam di Indonesia masih dominan berorientasi pada ekonomi, atau menjadikannya komoditas, bukan dalam rangka menjaga keberlangsungan ruang hidup manusia dan ekologis secara lebih baik.

Konflik tersebut disebabkan oleh disain politik hukum yang justru kerap 'merawat kepentingan

36 Tandiono Bawor (ND), "Dayak Limbai Pelaik Keruap Melawan Tambang”, paper, https://docs.google.com/document/ d/1GiouOWZlSJ2jRPxFihVcyh7afItK_j0Agm eO7mAV9rg/edit, diakses 10 Oktober 2013. 
akumulasi modal' di sektor sumberdaya alam. Di sisi lain, 'ego-sektoralisme' berkaitan dengan pengelolaan sumberdaya alam masih dominan terjadi. Belum lagi, ditambah problem tumpang tindih dalam pengeloalan sumberdaya alam dan nir perlindungan hak masyarakat adat.

Dalam sistem hukum Indonesia, khususnya dalam konteks struktur ketatanegaraan, peradilan adat menjadi menguat posisinya karena realitas politik desentralisasi secara secara lebih terbuka memberi ruang demokratisasi lokal, termasuk memunginkan menumbuhkan partisipasi politik kewargaan secara luas. Dorongan untuk memberi posisi atau kedudukan lebih kuat terhadap bekerjanya mekanisme peradilan adat, tak serta merta menjadikannya otomatis kuat. Faktanya, bisa sebaliknya. Penundukan hukum negara atas hukum rakyat, melalui penggunaan peradilan adat sebagai instrumentasi hukum baru yang keberdayaan sosialnya melemah.

Karena peradilan adat masuk dalam pusaran politik ekonomi yang demikian, ia tak hanya memodifikasi keberlakuan peradilan adat, namun pula melumpuhkan keberdayaan peradilan itu sendiri. Akibatnya, keberlakuan peradilan adat, secara bertahap akan melahirkan sekadar simbolisasi kuasa feodalisme tertentu. Oleh sebab itu, bagian penutup ini mengakhiri dengan kritik.

Kritik atas studi peradilan adat yang lebih menempatkan eksistensi hukum atau kedudukannya dalam sistem hukum nasional, tanpa dilihat relasi politik-ekonominya, akan terjebak dalam pemikiran politik formalisasi atau negaraisasi. Diskursus atau kajiannya cenderung membawa arah peradilan adat ke situasi yang berkarakter hukum yang lebih melayani kepentingan elit dan represif.Kelemahan yang acapkali ditemui dalam analisis hukum terkait dengan eksistensi hukum rakyat (atau hukum adat), tidak boleh serta merta peradilan adat dipandang selesai dengan 'urusannya sendiri'. Artinya, tak senantiasa hukum itu bisa dipandang hadir tanpa atau 'steril' dari cerminan politik kekuasaan tertentu. Apalagi, kajian peradilan adat dianggap tidak terhubung dengan persoalan universalitas dan dignitas hak asasi manusia. Dalam prakteknya, tak sedikit hukum adat, sebagai realitas eksistensi yang bertahan dan dipertahankan, justru berlaku diskriminatif dan melanggar hak-hak asasi manusia. Cribb pernah pula menegaskan dalam argumennya, bahwa sebagian orang Indonesia terjebak dalam pemikiran hukum kolonial yang tidak melihat hukum sebagai representasi nilai-nilai universal melainkan sebagai representasi identitas (kultural) dan beraspek kekuasaan. ${ }^{37}$

Dengan kritik demikian, kajian peradilan adat tak senantiasa berujung pada diskusi perlukah menghadirkan peradilan adat dalam sistem hukum nasional, melainkan membacanya secara lebih kritis atas analisis suatu peradilan adat yang hadir dengan kecenderungan formalisme. Dalam artikel ini ditunjukkan bahwa sindikasi dalam kepentingan politik ekonomi dibalik keberlakuan peradilan adat, justru memperkuat dan melanggengkan kekuatan aliansi predatoris. Akibat jangka panjangnya, adalah praktek peradilan adat bila tidak diberi konteks kritik yang memadai akan mengakselerasi kehancuran sistem hukum lokal, termasuk mereproduksi hukum-hukum adat atau lokal yang fasistik.

\section{DAFTAR PUSTAKA}

\section{A. Buku}

Hadikusuma, Hilman, 1989, Peradilan Adat di Indonesia, Miswar, Jakarta.

Hooker, M.B., 1978, Adat Law in Modern Indonesia, Oxford University Press, Kuala Lumpur.
Laudjeng, Hedar, 2003, Mempertimbangkan Peradilan Adat, HuMa, Jakarta.

P. Wiratraman, Herlambang, et al., 2010, Antara Teks dan Konteks: Dinamika Pengakuan Hukum terhadap Hak Masyarakat Adat atas

37 Robert Cribb, "Legal Pluralism and Dutch Criminal Law and Colonial Order”, Indonesia 90, Oktober 2010, hlm. 47- 66. 
Sumber Daya Alam di Indonesia, Huma, Jakarta.

R. Hadiz, Vedi, 2010, Localising Power in PostAuthoritarian Indonesia: A Southeast Asia Perspective, Stanford University Press, Stanford.

Rahardjo, Satjipto, 2010, Sosiologi Hukum Perkembangan Metode dan Pilihan Masalah, Genta Publishing, Yogyakarta_

Risalah Sidang Badan Persiapan Usaha-Usaha Kemerdekaan Indonesia (BPUPKI)-Panitia Persiapan Kemerdekaan Indonesia (PPKI) Sekretariat Negara Republik Indonesia, Jakarta, 1995: 179-180.

Simarmata, Rikardo, 2006, Pengakuan Hukum terhadap Masyarakat Adat di Indonesia, UNDP, Jakarta.

Tresna, 1978, Peradilan di Indonesia dari Abad Ke Abad, Pradnya Paramita, Jakarta.

\section{B. Artikel Jurnal}

Hasan, Ahmadi, 2007, "Penyelesaian Sengketa Melalui Upaya (Non Ligitasi) Menurut Peraturan Perundang-Undangan", Jurnal $A L$ BANJARI, Vol. 5, No. 9, Januari-Juni 2007.

Steny, Bernadinus, "Politik Pengakuan Masyarakat Adat: dari Warisan Kolonial Hingga Negara Merdeka”, Jurnal Jentera Edisi Lingkungan, 2009.

Zulfa, Eva Achjani, "Keadilan Restoratif dan Revitalisasi Lembaga Adat Di Indonesia”, Jurnal Kriminologi Indonesia, Vol. 6, No.II, Agustus 2010, hlm. 182-203.

\section{Hasil Penelitian/Tugas Akhir}

Hasan, Ahmadi, 2007, Penyelesaian Sengketa Hukum Berdasarkan Adat Badamai Pada Masyarakat Banjar dalam Kerangka Sistem Hukum Nasional, Disertasi, Program Doktor Ilmu Hukum Pasasarjana Fakultas Hukum Universitas Islam Indonesia, Yogyakarta.

P. Wiratraman, Herlambang, et al., 2013, Peluang dan Tantangan Peradilan Adat dalam Sistem Hukum Indonesia: Studi Kasus Peradilan
Adat yang 'Melibatkan Pihak Luar', Laporan Pengkajian Badan Pengkajian Badan Pembinaan Hukum Nasional (BPHN), BPHN, Jakarta.

P. Wiratraman, Herlambang, 2013, Peradilan Adat dan Utopia Kekuasaan?, Bulletin HuMa, Jakarta.

P. Wiratraman, Herlambang, et al., 2014, Politik Hukum Nasional terhadap Perlindungan Hukum Masyarakat Hukum Adat, Analisis Harmoni Perundang-undangan Berkaitan Sumberdaya Alam (Studi Kehutanan, Perkebunan, Pesisir dan Kelautan), Laporan Pengkajian Badan Pengkajian Badan Pembinaan Hukum Nasional (BPHN), BPHN, Jakarta.

\section{Makalah}

Abdurrahman, 2002, "Peradilan Adat dan Lembaga Adat dalam Sistem Peradilan Indonesia", makalah, disampaikan dalam Sarasehan Peradilan Adat Kongres Aman II, Mataram, 20 September 2002.

Arizona, Yance, 2012, "Kedudukan Peradilan Adat dalam Sistem Hukum Nasional", Makalah, disampaikan pada Diskusi tentang Memperkuat Peradilan Adat di Kalimantan Tengah untuk Penguatan Akses terhadap Keadilan, 11 Juni 2013.

Mulyadi, Lilik, 2013, "Hukum dan Putusan Adat dalam Peradilan Negara”, Makalah, untuk Dialog Nasional Bersama Perkumpulan HuMa dan Mahkamah Agung, Royal Kuningan, 10 Oktober 2013.

Rato, Dominikus, 2013, "Prinsip, Mekanisme dan Praktek Peradilan Adat dalam Menangani Kasus Hukum dengan Pihak Lain", Makalah, Focus Group Discussion, BPHN, Jakarta.

Simarmata, Rikardo, 2013. "Merumuskan Peradilan Adat dalam Sistem Peradilan Nasional", Makalah, disampaikan dalam Dialog Nasional Bersama Perkumpulan HuMa dan Mahkamah Agung, Royal Kuningan, 10 Oktober 2013 


\section{E. Antologi}

Hardiman, F. Budi, "Posisi Struktural Suku Bangsa dan Hubungan antar Suku Bangsa dalam Kehidupan Kebangsaan dan Kenegaraan di Indonesia (Ditinjau dari Perspektif Filsafat)", dalam Ignas Tri, Hubungan Struktural Masyarakat Adat, Suku Bangsa, Bangsa, dan Negara (Ditinjau dari Perspektif Hak Asasi Manusia), 2006, Komnas HAM, Jakarta.

Koesnoe, Muhammad, "Musyawarah”, dalam Miriam Budiardjo, 1971, Masalah Kenegaraan, tanpa penerbit, Jakarta.

Rahardjo, Satjipto, "Hukum Adat dalam Negara Kesatuan Republik Indonesia (Perspektif Sosiologi Hukum)", dalam Hilmi Rosyida dan Bisariyadi, 2005, Inventarisasi dan Perlindungan Hak Masyarakat Hukum Adat. Komnas HAM, Mahkamah Konstitusi RI, dan Departemen Dalam Negeri, Jakarta.

\section{F. Artikel Koran}

P. Wiratraman, Herlambang, 2009, “Ganyang Mafia?", Kompas, 10 Oktober 2009.

\section{G. Internet}

Detik News, "Tunggakan 8 Ribu Perkara Tiap Tahun Jadi Tantangan Ketua MA Baru', http://news.detik.com/read/2012/02/06/ 190613/1835694/10/tunggakan-8-ribuperkara-tiap-tahun-jadi-tantangan-ketua- ma-baru?nd992203605, diakses 10 Agustus 2018. Lihat juga catatan dari SAJI Project, Pedoman Peradilan Adat Sulawesi Tengah, 2013.

Bawor, Tandiono, (ND), "Dayak Limbai Pelaik Keruap Melawan Tambang”, paper, https://docs.google.com/document/ d/1GiouOWZlSJ2jRPxFihVcyh7afItK_ j0Agm eO7mAV9rg/edit, diakses 10 Oktober 2013.

\section{H. Peraturan Perundang-undangan}

Undang-Undang Dasar Negara Republik Indonesia Tahun 1945.

Undang-Undang Darurat Nomor 1 Tahun 1951 tentang Tindakan-Tindakan Sementara untuk Menyelenggarakan Kesatuan Susunan Kekuasaan dan Acara Pengadilan-Pengadilan Sipil (Lembaran Negara Republik Indonesia Tahun 1951, Nomor 9, Tambahan Lembaran Negara Republik Indonesia Nomor 81).

\section{Putusan Pengadilan}

Putusan Mahkamah Konstitusi Nomor 3/PUUVIII/2010 perihal Pengujian Undang-Undang Republik Indonesia Nomor 27 Tahun 2007 tentang Pengelolaan Wilayah Pesisisr dan Pulau-Pulau Kecil terhadap Undang-Undang Dasar Negara Republik Indonesia Tahun 1945. 